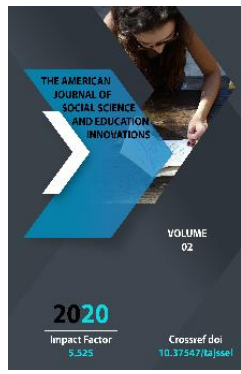

\title{
In The Studies Of The Late XIX And Early XX Centuries Issues Of Silk Factory Of Turkestan Region
}

\author{
Alimova Nargizaxon Odilovna \\ Doctor Of Philosophy In History, Fergana State University, Uzbekistan
}

Copyright: Original content from this work may be used under the terms of the creative commons attributes 4.0 licence.

\section{ABSTRACT}

This article describes the peculiar contradictory changes that took place in the silk industry of Turkestan in the late 19th and early 20th centuries. Research in the late 19th and early 20th centuries also covered the situation in the silk industry during the reign of the Russian Empire.

\section{KEYWORDS}

Silkworm breeding, cocoon production, raw materials, seed enterprises, artisans, silk fabrics.

\section{INTRODUCTION}

At the stage of modern development, the countries of the world pay great attention to expanding their economic potential, including the cultivation of natural silk fiber, an important raw material for industrial enterprises. In particular, silk production is recognized as one of the most important industries in Uzbekistan. In order to develop the silk industry, over the past years, a modern material and technical base of the industry has been formed, the silk system has completely changed.It also paved the way for international cooperation in trade in silk products and exchange of experience. As the President of the Republic of Uzbekistan Sh. Mirziyoyev noted, "Silkworm breeding is our national 
value, our wealth. It can be harvested up to three times, produce ready-made fabrics and earn a lot of money. "[1].

During the years of independence, based on the scientific research of Uzbek scientists, it isbelieved that silk originated in Central Asia. Uzbek scholars have cometo the conclusion that silkworm breeding originated and developed independently in Turkestan. In addition, the geographical location of the country for silkworms, the availability of irrigated land for mulberry plantations, sedentary population have created conditions for the development of this industry. This field is known among the branches of Uzbek handicrafts as a wonderful practical profession, which creates extremely high works of art.

From ancient times, silkworm breeding has been an important branch of agriculture and handicrafts in our country. In Central Asia, especially in Turkestan, silk has long played an important role in the way of life of the population. In the country, silk-vegetable fiber from cocoons can easily compete with cottonfiber yarn.

After the occupation of Turkestan by the Russian Empire, the socio-economic life of the country underwent dramatic changes. The metropolis turned the country into a raw material base and paid great attention to the cotton, silk and other important industries. In the field of industrial construction, the Russian Empire, in the interests of the metropolitan bourgeoisie, supported the construction of primary processing plants for raw materials, although it hindered the development of the finished goods industry in Turkestan.

In the late XIX - early XX centuries, the majority of the population living in Namangan,
Margilan, Andijan districts were engaged in the silk industry. In the Fergana Valley, the cities of Margilan and Namangan are considered to be rich in silk-making traditions.

\section{MATERIALS AND METHODS}

In the Turkestan region, there have been some contradictory changes in the silk industry. The same situation is reflected in the research of the late XIX and early XX centuries. In particular, the research of the late XIX and early $X X$ centuries reflected the peculiarities of the silk industry during the reign of the Russian Empire. In particular, important information about the types of silkworm seeds in the country, their care, processing of raw materials, weaving and types of silk fabrics, prices, sales and income from silk, the activities of silk enterprises, artisans [4].

In particular, in the research of the late XIX early XX centuries, we can partially consider the data on the field. For example, A. Polevitsky in his work "Turkestan region" noted that Kokand and Margilan were the main centers of silk production [5]. According to the data on the price of raw silk, the price of raw silk in European markets has risen sharply, including 1 pound - from 240 to 350 rubles.

In his study "Production forces of Turkestan" N.I.Malakhovsky gave the following information about the places (points) of silk production. In other words, among the Turkestan regions there are 84 silk-growing points in Syrdarya region, 157 in Samarkand region, and 304 in Fergana region [6].

N.D. Ignatev in his article "The issue of restoration of the Khorezm silk industry" gave the following information about the situation in the industry. In particular, the government of the Russian Empire did not pay enough 
attention to the quality of silkworm seeds, so in the 70s and 80s of the XIX century there was a disease among silkworms [7], the existing local silkworm breeds become extinct, and the silk industry begins to decline. In our opinion, the colonial administration in the country was forced to take measures based on its economic interests, such as the establishment of silkworm breeding stations to produce quality seeds in order to prevent a crisis in this area (as in European countries - the author).

According to experts of the time, the most delicate silk-producing variety was the Chinese silkworm. However, caring for it was a much more complicated process. Since the type "Corsica" [8] (due to natural climatic conditions) was more suitable for Turkestan conditions, the purchase and cultivation of this silkworm seed was widely promoted among the population. According to A.Wilkins's article "A few words about the hydraulic stations in Turkestan", seed stations were soon established in cities such as Margilan and Samarkand, and silkworm seeds were distributed free of charge to the population[9].

In the country, silkworm breeding in the Fergana region accounted for a large volume of domestic production. The seed station in New Margilan has played an important role in this regard.

In V.N.Ogloblin's study "Industry trade of Turkestan", he reported that the New Margilan station consists of small rooms and has 2 specialists working with a microscope. It was also stated that it was not possible to produce the required amount of products at the New Margilan station and to check the quality of all silkworm seeds imported [10].

In particular, according to I.I.Geyer's study "Guide to Turkestan", local and foreign entrepreneurs are trying to build silkworm breeding stations, as well as to bring to Turkestan high-quality silkworm seed species from France and Italy, they did. He also noted that since 1890, Aloizi had been importing quality silkworm seed varieties from Corsica to a country without any competition and had established a large silkworm seed factory and a private silk school in Fergana. Data on cocoon yield were also included. For example, in 1901, 5,500 poods of cocoons were harvested in the Syrdarya region, in the same year, 191,300 silkworm seeds were revived in the Samarkand region, and 6,003 poodsof cocoons were harvested [11].

According to A.I.Shakhnazarov, the number of private silkworm breeding enterprises in the country has increased since 1898, and the largest of them are BerteMandalaki in Kokand and Eutyhidin in Fergana. There is also information about the opening of private silkworm breeding enterprises in $\mathrm{New}$ Margilan in 1899 by Evtixidi, a specialist in silkworm breeding, and in 1901 by Berte Mandalaki and Eliftariads in Kokand.

\section{RESULT AND DISCUSSION}

V.V. Zaorskaya, K.A. Alexander's research "Industrial establishments of the Turkestan region" states that in 1901 there were 7 worm seed enterprises in Fergana region, in 1907 there were 9 worm seed enterprises, as well as in Skobelev (Fergana), 2 in Margilan and Kokand. There were 2 (Mandalaki, Elifteriadi), 2 in Namangan (Chustda - Soteriadi, Namangan Ishkhanov), and in 19142 more enterprises were added to them. It was also noted that since the end of the XIX century the government has paid more attention to the construction of cocoon drying plants in the country, the first new type of cocoon drying 
plants was established in 1898 in New Margilan (Fergana). In 1907, 5 such enterprises were launched in Margilan district, and in 1908, 5 more in Kokand district. Due to the growing demand, the number of cocoon drying enterprises increased. In 1913, their number was 27 in Fergana region and 1 in Samarkand [12].

According to V.V.Zaorskaya, K.A.Alexanders, in 1913-1914 the number of enterprises producing silkworm seeds in Turkestan increased to 11, the number of workers was 1117, the number of cocoons was 31 and the number of workers was 2500, can learn about.There are also reports that 6 more cocoon drying enterprises were opened in the country during 1910-1914, and by 1914 there were a total of 28 cocoon drying enterprises in the country, most of which were located in Fergana region. The total production capacity of these enterprises in 1913 was 3,136,814 rubles, these enterprises were located mainly near railway stations, the number of workers was from 50 to 100 , only in 9 cocoon drying enterprises - 50 people, and in 2 - 200 people.

In the research of V.V.Zaorskaya, K.A.Alexanders there is also information on the gender composition of workers in existing enterprises. For example, the majority of workers $-56.5 \%$ - were local women, and a total of 2,198 workers were employed in cocoon drying facilities [13].

S.R.Konopka's book "Turkestan region" published in Tashkent contains information about the silk industry, as well as the existing industries in the Fergana region. For example, it is stated that the raw silk in Fergana region in 1903 amounted to 128,870 pounds [14].
In conclusion, the silk industry played an important role in the life of the Turkestan region in the late XIX - early XX centuries. Therefore, the pages of research in the late XIX - early XX centuries contain a lot of information about silkworm breeding.

\section{REFERENCES}

1. Fruitful mulberry variety made a great impression on our President // http://president.uz/uz/lists/view/1738 19.05.2018.

2. Askarov A.A. History of Uzbekistan. Tashkent: Teacher, 1994. - P.73; Xo'jaev A. The Great Silk Road: Relationships and Destinies. - Tashkent: National Encyclopedia of Uzbekistan, 2007. - B. 88; Berdimurodov A, Indiaminova Sh. The Great Silk Road: across continents and centuries. - Tashkent: Uzbekistan, 2017. P.23-24 .; Xo'jaev A. Information on the history of Fergana. - Fergana: Fergana, 2013. - P.55.

3. Makhkamova S. Uzbek abrovo fabrics. Tashkent, 1963 --- p. 8.

4. Khanykov N.V. Description of the Bukhara Khanate. - SPb., 1843 .-- 279 p .; Vambery A. Essays on Central Asia. - M., 1968. - 361 p .; Nazarov F. Notes on some peoples and lands of the Central Asia. - St. Petersburg, 1821. - $98 \mathrm{p}$.; Pashino P.I. Turkestan Territory in 1866 Travel notes. - SPb, 1868 .- 176 p .; Petrovsky N.F. Sericulture and silkworming in Central Asia. Report to the Ministry of Finance of the Agent in the Turkestan General Government. - SPb., 1874. - $160 \mathrm{p}$.; Agriculture in the Turkestan Territory. Compiled by A.I. Shakhnazarov. SPb., 1908. - S. 360-389; Timaev S. Sericulture in the Turkestan Territory. Feature article. - SPb., 1910 .-- 29 p .; Masalsky V.I. Turkestan region / Russia. Full 
geographical description of our fatherland. Ed. N.P. Semenov of Tien Shansk. Volume XIX. - SPb., 1874. - 858 p .; Polevitsky A. Turkestan Territory. - Ekaterinodar, 1890 .-$41 \mathrm{p} \mathrm{.;} \mathrm{Zaorskaya} \mathrm{V.V.,} \mathrm{Alexander} \mathrm{K.A.}$ Industrial establishments of the Turkestan region. - Petrograd, 1915 -- 557 p .; Ogloblin V.N. Industry and trade of Turkestan. - M., 1914. - S. 21, 22, 36 .; Malakhovsky N.I. The production forces of Turkestan. - SPb., 1909. - P. 6 -18 ; Maev N.A. Turkestan Exhibition 1886 - Tashkent: Publication of the Turkestan Department of the Imperial Russian Gardening Society, 1886. - pp. 8, 16, 22; Golovin G. Handicrafts of Turkestan. Tashkent, 1909 .- 35 p .; Nalivkin V.P., Nalivkina M. Essay on the life of a woman of the settled indigenous population of Fergana. - Kazan: Printing house of the Imperial University, 1886. - P. 114-117 .; Economic overview of the Turkestan region (served by the Central Asian railway) Compiled by S. Gulishambarov. Askhabad, 1913 .-- P. 39; Geyer I.I. Guide to Turkestan. - Tashkent, 1901. - P.28-32; Konopka S.R. Turkestan region. - Tashkent, 1913. - p. 240; Dobrosmyslov A.I. Tashkent in the past and present. Historical sketch. Tashkent: Typolithography O. A. Portsev, 1912. - p. 389.

5. Polevitsky A. Turkestan Territory. Ekaterinodar, 1890 .-- P. 41.

6. Malakhovsky N.I. The production forces of Turkestan. - SPb., 1909. - P.6, 9.

7. Ignatev N.D. The issue of restoring the Khorezm silk industry // Sredneaziatskiy shelkovodstvo. - 1925. № 1. - p. 124.

8. Corsica is an island in the northern part of the Mediterranean Sea. (National Encyclopedia of Uzbekistan. Volume 5. Tashkent: National Encyclopedia of Uzbekistan Publishing House, 2003. - P.47.)
9. Wilkins A. A few words about the ditch stations of Turkestan // TV. - 1889. - No. 12.

10. Ogloblin V.N. Industry and trade of Turkestan. - Moscow, 1914 --- p. 5.

11. Geyer I.I. Guide to Turkestan. - Tashkent, 1901. - S. 150, 204.

12. Agriculture in the Turkestan Territory. Compiled by A.I. Shakhnazarov. - SP, 1908 .- S. 379.

13. Zaorskaya V.V., Alexander K.A. Industrial establishments of the Turkestan region. Petrograd, 1915 .-- S. 178, 182, 197.

14. Konopka S.R. Turkestan region. - Tashkent, 1913 .- p. 240. 